\author{
Savchenko O. O., \\ Candidate of Philological Sciences, \\ Department of Comparative Pedagogy and Methodology of Teaching Foreign Languages \\ Drohobych Ivan Franko State Pedagogical University
}

\title{
PAREMIOLOGICAL MANIFESTATION OF ENTHOCULTURAL COMPONENT OF MEANING
}

\begin{abstract}
Summary. The article is devoted to the problem of verbalization of ethnocultural component in such language items as paroemias. Paroemias are folk expressions of instructive content, constructed mostly as syntactically and semantically complete, reproducible sentences that express certain rules of life or truths in a concise form, literally or figuratively. Paremiological fund is the brightest layer of a language which most expressively reflects the national outlook and culture. It comprises the shortest genres that figuratively reproduce the most significant phenomena and realities of life: proverbs, sayings, riddles, greetings, wishes, curses, comparisons, superstitions, puns, toasts etc. The identification of semantic ethnocultural component in paroemias leads to modelling the national linguistic picture of the world. Under the ethnocultural component of meaning we understand information that highlights various geographical, social, ethnographic and historical information and conveys associative and figurative collective ideas of native speakers. It is established that the ethnocultural component of meaning is revealed through the lexical composition of a paroemia (individual components or in its interaction with other lexical units of a paroemia), a direct plan of content or phraseological meaning of a paroemia. It is proved that the means of reflecting the national and cultural specifics of paroemias is mainly a figurative basis. Its interpretation is the content of the ethnocultural component of meaning, because the national-cultural specificity is most fully manifested in the hidden semantic components. Other basic principles contributing to the identification of ehnocultural specifics are: the interlingual comparison of paroemias, which provides profound results in clarifying the universal and idioethnic in these language units, as they cannot be received by way of analyzing only one language system; culturological value, thematic affiliation, frequency of usage, relevance, semantic complexity (presence of more than one meaning, positive word-forming potential, etc.).

Paroemias with a direct meaning or the internal form of figurative paroemias convey collective ideas about various aspects of the life of the ethnos - house and farm management, natural living conditions, history, customs, and so on. The figurative meaning of a paroemia, which is based on the associative-figurative component, also gives cultural information related to the spiritual life of an ethnos - values, morals, symbols.
\end{abstract}

Key words: paroemia, proverb, saying, ethnocultural component of meaning, concept.

Problem statement. In order to decode the knowledge of the world, it is advisable to address the actual paroemias as a creative product of a particular ethnos. Cognitive processes are concentrated in these language units: the ethnos' knowledge of the realities of the environment and the reproduction of practical experience in different periods of its development, the memory of different generations about the past, which is also the knowledge of the environment, are reflected in them. In addition, paroemias, like language in general, are representatives of the culture of the people.

The aim of this article is the study of the ethnocultural specificity of the paroemias which presupposes an immersion in the linguistic and, through it, spiritual culture of both the individual representative of the ethnos and the entire linguocultural community. Analysis of ethnocultural components in language is an important area of modern linguistic research, as it helps to define the peculiarities of the mentality and culture of a specific ethnic group. Because of this, paroemias are a favourable material for identifying the ethnocultural component of meaning, national cultural traits, worldview and mentality, as well as the study of the conceptualization and categorization of reality by representatives of different linguocultural communities. According to researchers, national-cultural semantics is attested at all levels of language: in grammar, syntax, and even in phonetics. However, it is most pronounced in the so-called structural units of language, which directly reflect the extralinguistic reality, call objects and phenomena of the world. Such units include words, idioms and paroemias.

Analysis of recent research and publications. Interest in paremiology as a science is growing in the late 20th - early $21^{\text {st }}$ century in both foreign and national linguistics. The issues related to the semiotic, semantic and communicative-pragmatic nature of these language units are the most deeply studied. In general, paroemias have repeatedly been the subject of research in paremiology (works by N. Barley, A. Dandis, E. Kokare, H. Permiakov, W. Mieder), as well as in linguistics (researches by I. Holubovs'ka, O. Levchenko, O. Kononenko, Z. Kotsiuba and others), however, many aspects of the analysis of proverbs and sayings related to the problems of studying human consciousness, perception and awareness of the world haven't received due attention by scientists.

Discussion. Due to its diversity, the concept of "paroemia" does not have a clear definition. Many researchers classify them as phraseological units. In particular, the Ukrainian researcher Z. Kotsiuba interprets "proverbs and sayings as a special group of linguistic units of communicative type within the phraseological level, which, despite all attempts of structural paremiologists to build a coherent system of paremiological models, is not homogeneous in structure or semantics nor by functions" [1, p. 74].

O. Dudenko presents the following specific features of paroemias: instructiveness and evaluative content; the presence of grammatically and intonationally designed judgment; conciseness 
of expression; generalization of certain laws, rules of life or truths; a kind of closed, stable, reproducible and integral sentence of closed structure; clarity of functional purpose [2, p. 15].

As a precedent, a paroemia is a reproduced and self-sufficient complex verbal sign, the sum of the values of the components of which is not equal to the meaning. Precedent text is a unit of text level, the invariant of perception of which is part of the cognitive base, and the text itself is known to all members of the linguistic and cultural community [3, p. 251].

Paroemias are also characterized as precedent texts, given their independent status as a form of text. Precedent text is a unit of text level, the invariant of perception of which is part of the cognitive base, and the text itself is known to all members of the linguistic and cultural community [3, p. 251].

A paroemia is based on conceptual categories. In linguistics, this term denotes conceptual, mental categories. The structural and semantic structure of paroemia makes it possible to replace a large scope of thoughts with a concise associative image.

We determine the semantic structure of a paroemia, taking into account the cognitive nature of the precedent statement. Deep meaning is not formed on the basis of adding the semes of its components, but is the result of a semantic combination of components of the lexical and grammatical structure. As a result of such cognitive mechanisms in semantics there is a formation of a new meaning of the whole expression. The systemic meaning of a paroemia is a combination of deep meaning and knowledge of the precedent phenomenon and its associated connotations. The surface meaning of a paroemia is derived from the sum of the semes of its components.

The development of the semantic content of a paroemia is accompanied by a figurative rethinking of the realities of the environment, which results mainly in the loss of denotative meanings by the lexical units of a paroemia, the acquisition of connotations that indicate the connection of associativefigurative basis with culture (standards, symbols, stereotypes). The use of a paroemia in a figurative sense reproduces generalized, typical phenomena. The figurative meaning of a paroemia is formed as a consequence of the metaphorical one.

The term "paroemia" is ambiguous. In ancient times, paroemias were called short expressions that were written on roadside poles. They also denote passages from the book of the Old Testament (from the Greek "paroemia" - parable), which contain prophecies or teachings and are read in the Orthodox Church during the service. It was not until later that the term came to be used to refer to all teachings, parables, and wisdom. In encyclopedic works the following interpretations of a paroemia are given: "a folk expression expressed by a sentence, as well as a short chain of sentences that convey an elementary scene or the simplest dialogue" [4, p. 169].

From the point of view of both linguistics and folklore, the paremiological corpus unites the shortest genres that figuratively reproduce the most significant phenomena and realities of life: proverbs, sayings and their genre varieties - greetings, wishes, curses, comparisons, superstitions, puns, toasts [5, p. 536]. Paroemias include proverbs, sayings, riddles, omens, religious beliefs, prophetic dreams, divination, problems, puzzles, colloquialisms, orders, fables, puns, fairy tale formulas, and more.

It is noteworthy that riddles and proverbs complement each other: the former describe the material world, the physical world, and the latter the human world. Apart from this, there is another link between them: proverbs, sayings, as well as riddles, are concise and compact and use archaic structures and can merge into one another. The transformation of a saying into a proverb can take place by rearranging or changing words, so that the a saying acquires a generalizing meaning instead of a specific one. A separate figurative part of the riddle can sound like a proverb: they are identical signifiers, and their signified concepts are also identical, and the only difference is that in the case of a proverb the signified is clear from the context. These language units are united by another characteristic: from the point of view of national-cultural specificity they are the most marked layer of language, and from the point of view of cognitive linguistics they objectivize the content of the interpretive field of the concept of national-linguistic picture of the world. Reproduction of the semantics of ethnocultural concepts is the prerogative of paroemias, because they mark concepts that have an axiological character.

Paroemias in their entirety are paremiological corpora of languages. Differential characteristics of paroemias are conciseness, stability, reproducibility, rethought or literal generalized meaning, mostly instructive content. They convey information about traditional values and views based on the life experience of the people and depict typical life situations [6, p. 16].

Paroemias are folk expressions of instructive content, constructed mostly as syntactically and semantically complete, reproducible sentences that express certain rules of life or truths in a concise form, literally or figuratively. The key components of the actual paremiological corpus, according to most scientists, are proverbs and sayings, which are "interpretive acts", signs of folk culture, function as an "archive" of folk wisdom. They most clearly generalize the experience of the people, their comprehension of reality, human relations, the inner world of a human being. Nonetheless, proverbs and sayings have some differences, so they should be distinguished.

"Proverbs are stable expressions of mainly folklore origin which retain the experience of the people and their evaluation of various facts and phenomena" [7, p. 492]. Thus, a proverb is an instructive expression of folk origin, often rhyming, which conveys a particular truth of life or a rule based on the observations of the people, their experience. One of the typical features of proverbs is syntactic completeness. A proverb is based on a judgment that correlates with the meaning of the whole sentence and can be affirmative or negative. Proverbs can convey a direct (derived by the nominative meaning of component words) or a generalized metaphorical, i.e. figurative meaning.

As for sayings, they are formed as a sentence or part of a sentence, but do not have an instructive nature, but only characterize a phenomenon, event or person. Ukrainian lexicographical sources interpret the term "saying" as follows: "a saying is a stable expression of mainly folklore origin, which figuratively reveals a certain phenomenon primarily in terms of its emotionally expressive assessment [7, p. 487].

In order to learn about the nation's mentality, culture, way of life we can resort to analyzing ethnocultural component of semantics. Under the ethnocultural component of meaning we understand information that highlights various geographical, social, ethnographic and historical information and conveys associative and figurative collective ideas of native speakers. It is a constituent part of a semantic structure of the word, which 
reflects the connection between culture and language and which is determined by culture, living conditions of the people. According to T.A. Kosmeda, ethnocultural component of lexical meaning of the word in some lexical meanings can take a place directly in the denotative-significant meaning, and in others - is characterized as pragmatic component, ethnosemantic background of the lexical meaning of the word $[8$, p. 62].

Linguistic elements through which one can trace national specificity are paroemias, which are part of culture, a reflection of the people's thinking, their worldview, character, history, way of life, and so on. The linguistic and cultural value of paremiological units is that they reflect the uniqueness of the worldview of the language community and represent the most transparent concepts of culture embodied in linguistic means. It is in phraseology that the experience of many different peoples with their own peculiarities, which make up the identity of each nation, has been accumulated.

The means of reflecting the national and cultural specifics of paroemias is primarily a figurative basis. Its interpretation is the content of the ethnocultural component of meanings, because the national-cultural specificity is most fully actualized in the hidden semantic components.

However, the national-cultural component of semantics can be revealed through the direct meaning of paroemias, because such paroemias help to reveal the original naive ideas about the world of the people, its realities, domestic and farm life, economic life, traditions. The internal form of paroemias is also a source of information related to the cultural component of meaning in figurative paroemias. A detailed analysis of the information objectivized in internal forms helps to understand the naive conception of the world by the native speakers and some traits of their national character.

In regards to the knowledge of the ethnic mentality through paroemias, we can also talk about the presence of ethnopsychological background in them. The analysis of paroemias cannot be accomplished without attention to the reflection in them of the national identity, temperament, mindsets, prejudices all that is within the scope of the study of national psychology. Paroemias reflect both stereotypes of human behavior and socially important realities that can be the subject of simultaneous research in linguistic and cultural aspects.

Researcing paroemias in linguistics involves not only linguocultural, but also linguocognitive analysis. The cognitive method of studying paroemias is important for the study of ethnocultural semantics of these language units, because for them denotative-significant aspect is of less importance than connotative one, particularly different connotations, emotions, images.

Speaking about the process of forming the figurative basis of phraseology, V. Hak emphasizes that first a specific prototype situation is formed, which correlates with the direct meaning of phraseology. As a result, its meaning is reinterpreted on the basis of the initial meanings of words in the prototype situation. It is these original words that form their meaning in the image. This is how the internal form emerges, which contains basic information related to the culture, values, symbols of linguistic and cultural communities. In the future, phraseology functions as specific symbols, standards of culture [9, p. 54].

Thus, paroemias convey cultural information both through direct meaning and through a figurative basis and related connotations.
Considering this, it is obvious that the systematic understanding of paroemias is important for linguoculturology and ethnolinguistics in general. The ultimate goal of such a research is a comparison of the whole paremiological corpora of different languages.

By researching paroemias, we gain knowledge about national character, mentality, superstitions, moods, customs etc. Certain stereotypes of behavior, realities of life, values are reflected in them. Thus, one of the main goals of modern linguistics is to clarify both the specifics of the mentality of the people through language and culture of the people, reflected in paremiological patterns.

In fact, conceptual research methods create an attractive field for the implementation of the principles of linguistic and cultural analysis. Selection and presentation of culturological knowledge should be carried out taking into account such important criteria as culturological value, thematic affiliation, frequency of usage, relevance, semantic complexity (presence of more than one meaning, positive word-forming potential, etc.).

The main basic principle of identifying the ethnocultural component of meaning is the interlingual comparison of paroemias, which provides reliable results of identifying the universal and idioethnic in these language units, "which cannot be obtained by considering a single analyzed language system" $[10, p$. 409].

Paroemias can convey ethnocultural semantics in three ways: 1) in the phraseological sense, i.e. the total meaning of all components; 2) through the meaning of a single component or in semantic relations with other components of paroemia; 3 ) in their direct context.

The national-cultural component of meaning is manifested in all components of the concept: in the conceptual, figurative and value, except for the denotative direct semes of the name-concept, specified in explanatory dictionaries. Paremiological verbalization of the concept complements its lexical verbalization.

Other factors that should be taken into account during the procedure of identifying ethnocultural components are: 1) the factor of paremiologcal variability of the studied component; 2) the frequency factor of the component under analysis; 3 ) the factor of quantitative representation of a certain thematic group of paroemias. Regarding the latter, as noted by Z. Kotsiuba, "taking into account the factor of quantitative representation of the paremiological corpus makes it possible to understand how important, interesting or painful the relevant topic is for the collective author of the proverbial corpus. What the people live on always acquires a wide and diverse coverage, which leads to a significant quantitative representation of the paremiological corpus or thematic group" $[10$, p. 50].

Conclusions. Paremiological fund due to its diversity and content almost fully reflects the national culture, reveals the ethnolinguistic consciousness, creating a national conceptosphere. The ethnocultural component of meaning is revealed through the lexical composition of a paroemia (individual components or in its interaction with other lexical units of a paroemia), a direct plan of content or phraseological meaning of a paroemia. Paroemias with a direct meaning or the internal form of figurative paroemias convey ideas about various aspects of the life of the ethnos - house and farm management, history, customs, and so on. The figurative meaning of a paroemia, which is based on the associativefigurative component, also broadcasts cultural information related to the spiritual life of the ethnos - values, morals, certain symbols of the ethnos, and so on. 


\section{References:}

1. оцюба 3.Г. Лінгвістичні аспекти дослідження прислів 'їв і приказок Лінгвістичні студї : збірник. наук. праць. Донецьк : ДонНУ, 2012. № 24. C. 74-79.

2. Дуденко О.В. Номінативна та комунікативна природа українських паремій : дис. ... канд. філол. наук : 10.01.01. Умань, 2002. 218 с.

3. Гудков Д.Б. К вопросу о словаре прецедентных феноменов. Культурные слои во фразеологизмах и дискурсивных практиках / за ред. В.Н. Телия. Москва : Языки славянской культуры, 2004. C. $251-259$

4. Мала філологічна енциклопедія / уклад. О.І. Скопненко, Т.В. Цимбалюк.

5. Лановик М.Б. Українська усна народна творчість : підручник. 3-е вид. Київ : Знання-Прес, 2005. 591 с.

6. Алефиренко Н.Ф. Фразеология и паремиология : учебное пособие для бакалаврского уровня филологического образования. Москва, 2009. $344 \mathrm{c}$.

7. Українська мова : енциклопедія / НАН України, Ін-т мовознав. ім. О.О. Потебні, Ін-т укр. мови ; редкол. : В.М. Русанівський та ін. 2-ге вид., випр. і допов. Київ : Вид-во «Українська енциклопедія» ім. М.П. Бажана, 2004. 820 c.

8. Космеда Т.А. Денотат, конотація й аксіосемантика у проекції на лексико-семантичні відповідники російської та української мов. Мовознавство. 1997. № 4-5. С. 58-63.

9. Гак В.Г. Фразеорефлексы в этнокультурном аспекте. Филологические науки. 1995. № 4. С. 47-55.

10. Коцюба 3.Г. Рефлексія побутової свідомості в різномовному провербіальному просторі (від універсального до національного) : монографія. Львів : ДП «Видавничий дім «Укрпол»», 2010. 472 с.

Савченко О. Паремійна вербалізація етнокультурного компонента значення

Анотація. Стаття присвячена проблемі вербалізації національно-культурного компонента в таких мовних одиницях, як паремії. Паремії - це народні вирази повчального змісту, побудовані переважно як синтаксично та семантично завершені, відтворювані речення, що виражають певні правила життя чи істини в стислій формі, у прямому чи переносному значенні. Пареміологічний фонд - це найяскравіший шар мови, який найбільш виразно відо- бражає національний світогляд і культуру. Він містить найкоротші жанри, що образно відтворюють найважливіші явища та реалії життя: прислів'я, приказки, загадки, привітання, побажання, прокляття, порівняння, забобони, каламбури, тости тощо. Розкриття етнокультурного компонента семантики уможливлює моделювання національної мовної картини світу. Під етнокультурним компонентом значення ми розуміємо інформацію, яка висвітлює різноманітні географічні, соціальні, етнографічні й історичні факти та передає асоціативні й образні колективні ідеї носіїв мови. Установлено, що етнокультурний компонент значення розкривається через лексичний склад паремії (через окремі компоненти або у взаємодії з іншими лексичними одиницями пареміiі), прямий план змісту або фразеологічне значення паремійної одиниці. Зазначається, що засобом відображення національно-культурної специфіки паремій $є$ переважно образна основа. Ї̈ї тлумачення $€$ змістом національно-культурного компонента значень, оскільки національно-культурна специфіка найповніше об'єктивується в прихованих смислових компонентах. Іншими основними принципами, що сприяють виявленню етнокультурної специфіки, є міжмовне порівняння паремій, яке дає глибокі результати в 3'ясуванні універсального й ідіоетнічного в цих мовних одиницях, оскільки вони не можуть бути отримані шляхом аналізу лише однієї мовної системи; культурологічна цінність, тематична належність, частота використання, актуальність, смислова складність (наявність більше ніж одного значення, позитивний словотвірний потенціал тощо).

Паремії, яким властивий прямий план змісту, чи внутрішня форма образних паремій передають колективні уявлення про різноманітні реалії життя: господарсько-побутову сферу, історію, звичаї та традиції тощо. Непрямий план змісту паремійної одиниці, в основі якого лежить асоціативно-образний складник, також передає культурно марковану інформацію, яка здебільшого стосується духовного аспекту життя народу - морально-етичних цінностей, настанов, символів тощо.

Ключові слова: паремія, прислів'я, приказка, етнокультурний компонент значення, концепт. 